\title{
NEW RECORDS OF HYGROCYBE HYGROCYBOIDES (KÜHNER) ARNOLDS (FUNGI, BASIDIOMYCOTA, HYGROCYBEAE)
}

\section{T. Borgen \& D. Boertmann}

Borgen, T. \& Boertmann, D. 2008. New records of Hygrocybe hygrocyboides (Kühner) Arnolds (Fungi, Basidiomycota, Hygrocybeae). - Sommerfeltia 31: 17-27. ISBN 82-7420-045-4.. ISSN 0800-6865.

Recent collections from South Greenland and northern Sweden are referred to Hygrocybe hygrocyboides (Kühner) Arnolds, a species closely related to Hygrocybe pratensis (Pers.: Fr.) Murrill. These collections deviate slightly from the holotype both in macroscopic and microscopic characters. However, these differences are ascribed to intraspecific variation within this little known taxon. The new records of Hygrocybe hygrocyboides are the first outside The Alps.

Keywords: Greenland, Hygrocybe hygrocyboides, Hygrocybe pratensis, Sweden, taxonomy.

Torbjørn Borgen: Botanical Museum, Gothersgade 130, DK-1153 Copenhagen K, Denmark (mailing address: Sensommervej 142,DK-8600 Silkeborg, torbjoern.borgen@mail.dk)

David Boertmann: National Environmental Research Institute, Frederiksborgvej 399, P.O. Box 358, DK-4000 Roskilde,Denmarkdmb@dmu.dk)

\section{INTRODUCTION}

Hygrocybe hygrocyboides (Kühner) Arnolds is a very little known waxcap originally described from the French Alps (Kühner 1977). Since then, only Candusso (1997) has given a description of additional material from the Italian Alps. Some recent collections from Greenland and Swedish Lappland tentatively ascribed to H. hygrocyboides gave an opportunity to a closer study of Kühner's taxon, the results of which are reported here including observations on habitat and distribution of new records.

During the final adjustment of this manuscript we became aware of a new record of $H$. hygrocyboides from the Pyrenees. We have not studied this material, but it is mentioned in the present volume (Corriol 2008).

\section{MATERIALAND METHODS}

Eight collections including the holotype of $H$. hygrocyboides and ten collections of $H$. pratensis (Pers.: Fr.) Murrill were studied (see 'Specimens examined'). Material from Greenland, Denmark and Sweden was studied both in fresh and dried condition, the remaining only as exsiccata. Fresh specimens of H. hygrocyboides 
were sent by M. Karström in Sweden, to the second author. The holotype and other authentic collections of $H$. hygrocyboides were obtained as loan from Conservatoire et Jardin botaniques de la Ville de Genève $(\mathrm{G})$; the remaining collections from Botanical Museum of Copenhagen $(\mathrm{C})$, from the private herbaria of $\mathrm{M}$. Candusso (MC), M. Karström (MK) and T. Læssøe (TL), or are kept in our own herbaria (TB and DB). The collections at DB, TB and TL will be transferred to $\mathrm{C}$.

Microscopical characters were studied in water mounts (fresh material), in $10 \% \mathrm{NH}_{4} \mathrm{OH}$ or in $5 \%$ $\mathrm{KOH}$ (exsiccata). Spore-measurements were obtained mainly from mature spores deposited on the pileus surface or stipe apex. $\mathrm{Q}=$ spore length/spore width and av. = average. The colour codes refer to Munsell (1975) abbreviated Mu. and the notions in the descriptions, i.e. count of nuclei by the carmine-acetic method of Clemençon (1978), are the same as in Borgen \& Arnolds (2004). The notion 0.5R indicates that pileus striation reaches halfway to the centre. The concept "terminal elements" includes all terminal hyphae regardless their orientation, but does not include "proliferations" (i.e. terminal branches of hyphae).

\section{RESULTS}

Below are collections from Greenland and Sweden described in detail and compared to authentic material collected by Kühner including the holotype, and to a collection from Italy.

\section{Hygrocybe hygrocyboides (Kühner) Arnolds}

Persoonia 13: 386, 1987. - Basionym: Camarophyllus hygrocyboides Kühner, Bull. Soc. Mycol. Fr. 93: 144. 1977. Synonym: Cuphophyllus hygrocyboides (Kühner) Bon, Docums. mycol. 14 (56): 12. 1984. - Selected description: Kühner 1977.

Figs 1-4.

The Greenlandic collections

Description. Pileus 17-30(-38) mm broad, pulvinate to subumbonate, then more flattened, in age more or less depressed, margin straight, in age frequently uplifted, dry, slightly shiny, glabrous, margin not or indistinctly translucently striate, fairly dark orange-brown, centre near to Mu. $2.5 \mathrm{YR} 4 / 4$, paler towards the margin in places at most 2.5 YR $4.5 / 8$ to 5YR5.5/8, slightly hygrophanous, faded colours not recorded. Gills decurrent, subdistant ( $\mathrm{L}=18,1=1-3), 4.5 \mathrm{~mm}$ broad, rather thick, slightly intervenose, rarely furcate, pale orange-brown Mu. 7.5YR7/5-6, edge entire, glabrous. Stipe $20-23(-35) \times 4-5.5(-10) \mathrm{mm}$, fistulose, subcylindrical or slightly tapering downwards (base 4-4.5(-7) mm wide), whitish, occasionally aeriferous fibrillose especially at apex, ground colour pale brownish orange (near Mu. 5YR6.5/6) to more greyish. Context $1.5 \mathrm{~mm}$ thick 0.5R from pileus margin, concolorous, hygrophanous, smell indistinct, taste mild. Spore-print whitish.

Spores (6.9-)7.2-8.9(-10.6) ×(4.6-)4.8-6.0(-6.8) $\mu \mathrm{m}$, in average 7.8-8.4×5.3-5.5 $\mu \mathrm{m}, \mathrm{Q}=1.1-2.0$, Qav $=1.5$, inamyloid, ellipsoid, ovoid, occasionally subamygdaloid or lacrymoid, rarely with suprahilar depression, not constricted, globules rare, predominantly uninucleate $( \pm 85 \%)$. Basidia 4-rarely 2-spored, 37-63 $\times 6-8.5 \mu \mathrm{m}$, subcylindrical to subclavate, $\mathrm{Q}=4.6-8.7$. Gill edge fertile, cystidia not seen, basidioles present. Hymenophoral trama interwoven although \pm regular in mediostratum, elements $(21-) 39-112(-137) \times(4-) 5.5-16.5(-18.5) \mu \mathrm{m}$, subcylindrical to \pm irregular, in places subinflated; subhymenium very interwoven, made up of narrow hyphae. Pileipellis a radial to \pm interwoven, differentiated cutis, $20-40 \mu \mathrm{m}$ thick, the uppermost $(5-10 \mu \mathrm{m})$ layer of repent, partially slightly gelatinised hyphae with terminal elements (20-)26-64(-82) × 1.5-5(-5.5) $\mu \mathrm{m}$, in average 43.6-52.2 × 2.8-3.0 $\mu \mathrm{m}$, cylindrical, in places flexuose, tortuous to irregular, rarely tapering towards the obtuse ends; and a subpellis of repent to ascending, in places erect hyphae with some free ends, terminal elements (28-)29-41(-53) $\times 2-4 \mu \mathrm{m}$, in 

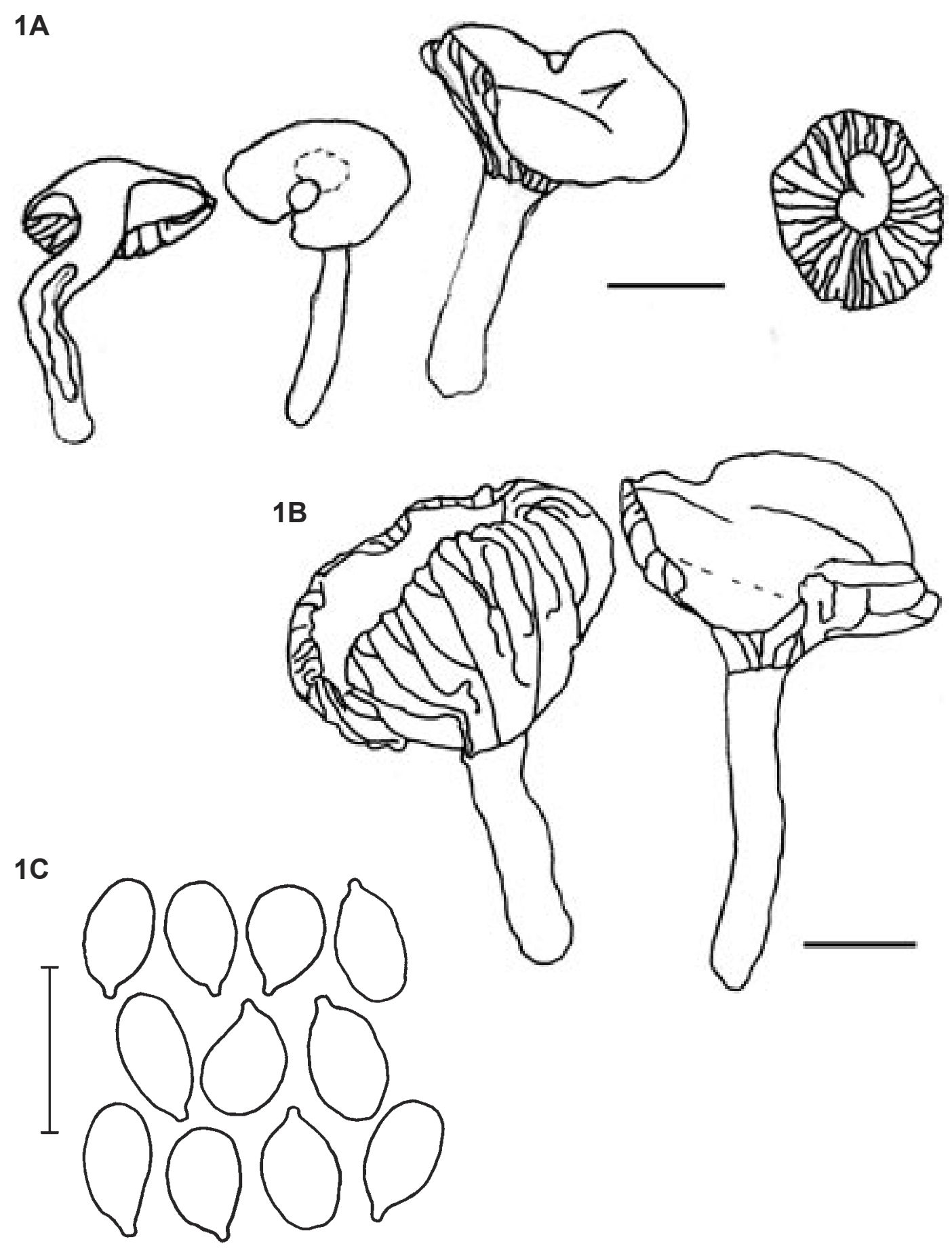

Fig. 1. H. hygrocyboides from Greenland. 1A carpophores of TB 02.152, 1B carpophores of TB 02.160, both collected at the same locality. Scalebar $=1 \mathrm{~cm} .1 \mathrm{C}$ spores of TB 02.152 , scalebar $=10 \mu \mathrm{m}$. 


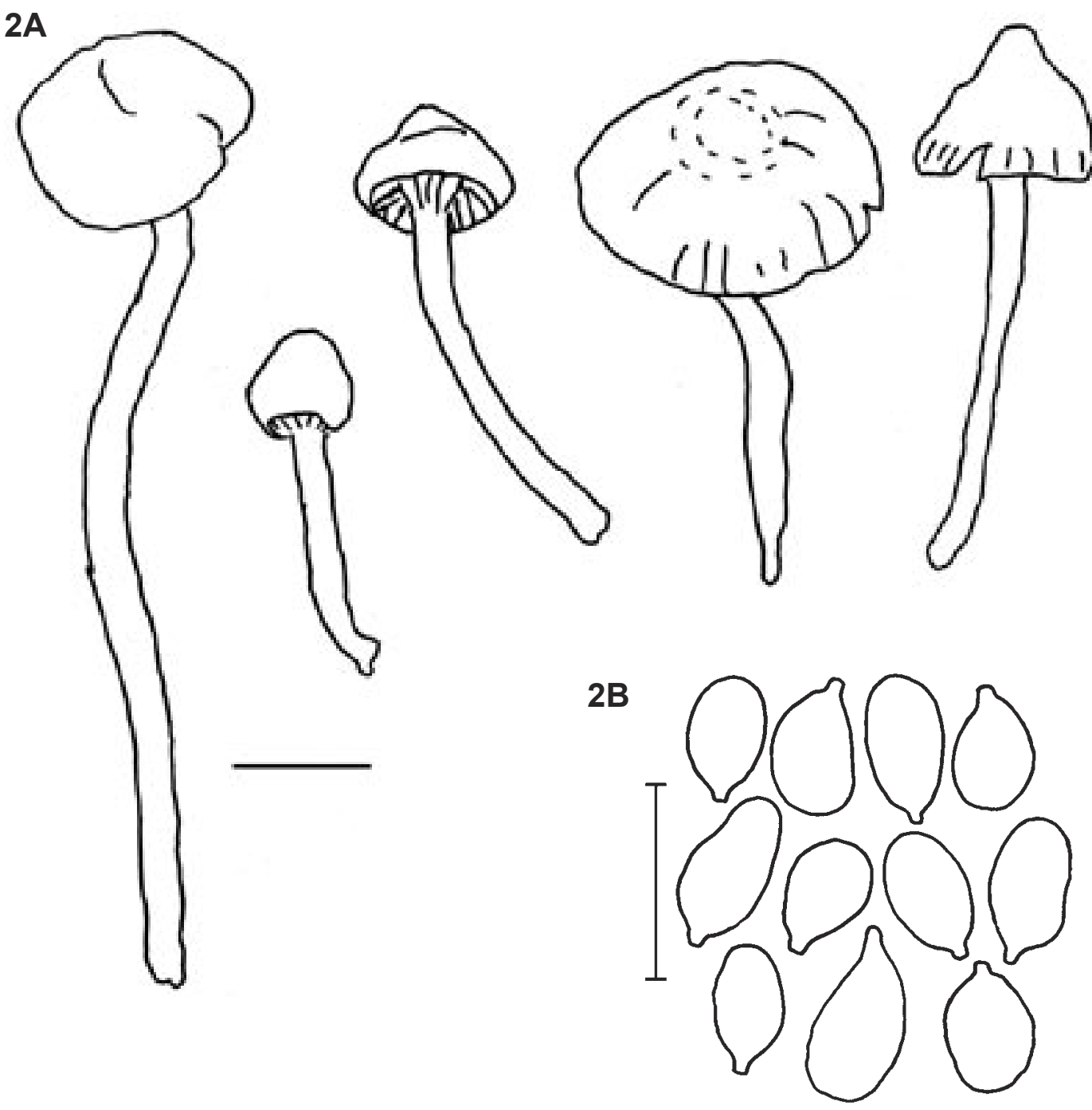

Fig. 2. H. hygrocyboides from Sweden. 2A carpophores of MK 0440 and s.n, scalebar $=1 \mathrm{~cm} .2 \mathrm{~B}$ spores of MK s.n. Scalebar $=10 \mu \mathrm{m}$.

average $34.6 \times 3.2 \mu \mathrm{m}$. Pileitrama (predominantly) subradial, elements $(20-) 35-83(-98) \times(4-) 5-12(-13.5) \mu \mathrm{m}$, (sub-) cylindrical, occasionally inflated or flexuose. Stipitipellis a thin cutis of radial, repent, (partly) ascending to erect hyphae, terminal elements (9-)19-91(-119) $\times 1.5-3 \mu \mathrm{m}$, in average 39.6-51.7 × 2-2.4 $\mu \mathrm{m}$, (sub-) cylindrical, in places flexuose, rarely subtortuous, ends obtuse. Stipititrama subregular, elements (29-)36-117(-127) × (6.5-) 8.5-16.5(-17.5) $\mu \mathrm{m}$, in average $93.3 \times 10.2 \mu \mathrm{m}$ or $49.9 \times 12.6 \mu \mathrm{m}$, subcylindrical to subinflated. Pigment intracellular, hyphae frequently thick walled, or encrusting; oleiferous hyphae present. Clamp connections present in all tissues, medallion clamps observed.

Habitat and distribution: Fasciculate in cushions of Alchemilla alpina in five places in ancient, dry grassland slope with several other grassland fungi (i.e. Hygrocybe, Clavulinopsis and Entoloma spp.), app, $150 \mathrm{~m}$ asl.; late 


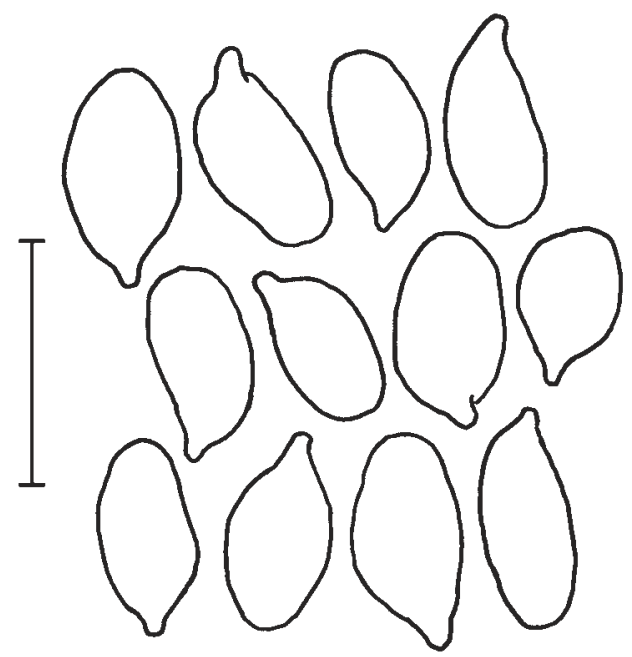

Fig. 3. Spores of holotype (Kühner 69.319) of H. hygrocyboides, scalebar $=10 \mu \mathrm{m}$.

August. The climate of the site is characterised as subarctic and subcontinental (Feilberg 1984).

Specimens examined: Greenland: (Two collections from the same site), Narsaq municipality, Narsarsuaq, Kiattuut Qaqqaat, TB 02.152 (C) and TB $02.160(\mathrm{C})$.

The Swedish collections

Description. Pileus 10-33 mm, more or less acutely campanulate, in age plano-convex and subumbonate, margin slightly incurved to decurved then straight, in age up to $0.5 \mathrm{R}$ translucently striate and occasionally subsulcate, dry, dull, glabrous, brownish orange with a slight golden flush, frequently darkest towards the centre, paler in age, hygrophanous, fading irregularly from the centre. Gills arcuate-decurrent, subdistant ( $\mathrm{L}=18-24,1=1-3)$, about 2.5-3.5 mm broad, fairly thin, slightly intervenose, furcate, buff to cream with reddish brown flush, paler in age, edge entire, glabrous. Stipe 32-73 × 2.5-4.5 mm, cylindrical to slightly attenuated, equal to subflexuose, dry, glabrous, slightly lustrous, in upper part pale innate aeriferous, fibrillose, probably worn off on lower part; yellowish buff with a slight reddish tinge in places, to pale watery orange. Context thin, firm, inodorous.

Spores (6.3-)7.2-8.9(-10.5) × (3.6-)4.4-5.6(-6.4) $\mu \mathrm{m}$, in average 7.7-8.1 × 4.7-5.1 $\mu \mathrm{m}, \mathrm{Q}=1.3-2.2$, Qav $=1.6-1.7$, inamyloid, predominantly ellipsoid, occasionally oblong, less frequently ovoid to subamygdaloid, without suprahilar depression, very rarely constricted, occasionally with globule; predominantly uninucleate $(85 \%)$. Basidia (31-)38-53(-58) $\times(5-) 5.5-7(-7.5) \mu \mathrm{m}, \mathrm{Q}=(5.1-) 6.7-8.2(-9.1)$, predominantly 4, rarely 3, 2-spored, predominantly subcylindrical. Gill edge fertile, cystidia not seen, basidioles present. Hymenophoral trama interwoven, in places subregular, elements (22-)28-49(-54) $\times(6-) 9-13.5(-14) \mu \mathrm{m}$, predominantly cylindrical, some inflated to irregular; subhymenium very interwoven, made up of narrow elements. Pileipellis a 15-35 $\mu \mathrm{m}$ broad, more or less differentiated cutis of radial, predominantly repent hyphae: the uppermost layer 5-10 $\mu \mathrm{m}$ thick, in places with gelatinized, terminal elements $(12-) 25-72(-145) \times(1-) 2-3.5(-4) \mu \mathrm{m}$, in average 50.3-53.6 $\times 2.7$ $\mu \mathrm{m}$, predominantly cylindrical, frequently undulate to subflexuose, in places inflated or attenuated, occasionally irregular; the elements in subpellis $(20-) 26-64(-82) \times(2.5-) 3-5(-6) \mu \mathrm{m}$, in average 45.4-50.9 $\times 3.4-4.6 \mu \mathrm{m}$. Pileitrama subradial, made up of loosely organized hyphae, elements (17.5-)31-65(-76) $\times(4.5-) 6-1$ 1,5(-13.5) $\mu \mathrm{m}$, predominantly (sub-) cylindrical. Stipitipellis a subradial, thin, compact cutis of predominantly repent hyphae, terminal elements $(20-) 37-81(-165) \times 1.5-3(-3.5) \mu \mathrm{m}$, in average 47.8-78.6 $\times 2.4 \mu \mathrm{m}$, cylindrical, ends obtuse. 
Stipititrama regular, elements (24-)45-117(-138) × (4.5-)6-10.5(-11) $\mu \mathrm{m}$, in average 68.9-88.0 × 7.2-7.4 $\mu \mathrm{m}$, predominantly subcylindrical. Pigment intracellular, hyphae in places (slightly) thick walled or encrusting; oleiferous hyphae present. Clamp connections present in all tissues.

Habitat: In grassland (lawn) at farm house with Hygrocybe and Clavaria spp. at app. $280 \mathrm{~m}$ asl. (M. Karström pers. comm.). The climate of the site is characterised as northern boreal and fairly continental (cf. Athi et al. 1968).

Specimens examined: Sweden (two collections from the same site), Lule Lappmark, Jokkmokk Municipality, Allojaur, 6 km NE of Jokkmokk, MK 0440 and MK sine no. (DB).

The Italian collection

Description. For macroscopic characters see Candusso (1997), cf. Tab. 1.

Spores (6.9-)7.8-9.6(-9.8) × (4.2-)4.4-5.4(-5.6) $\mu \mathrm{m}$, in average $8.7 \times 5.0 \mu \mathrm{m}, \mathrm{Q}=1.5-2.2$, Qav $=1.8$, ellipsoid, not constricted. Basidia (42-)43-53(-55) $\times(6.5-) 7-8(-8.5) \mu \mathrm{m}, 4$-spored. Hymenophoral trama interwoven, made up of short elements. Pileipellis of partly gelatinised hyphae, terminal elements (29-)41-83(-98) × $(1.5-) 2-2.5(-3.5) \mu \mathrm{m}$, in average $60.1 \times 2.2 \mu \mathrm{m}$; terminal elements in subpellis $(38-) 49-66(-110) \times(4.5-) 5-7.5(-$ 9) $\mu \mathrm{m}$, in average $59.5 \times 6.3 \mu \mathrm{m}$, obtusely subfusiform, rarely sublageniform or obtusely clavate, occasionally subflexuose, more or less constricted at septa. Elements in pileitrama (43-)49-68(-88) $\times(6.5-) 10-14(-16) \mu \mathrm{m}$, subcylindrical to subinflated, constricted at septa. Stipitipellis a subregular, dense cutis of repent to ascending hyphae, terminal elements (33-)39-83(-90) $\times(1.5-) 2-3$, in average $56.8 \times 2.3 \mu \mathrm{m}$. Stipititrama subregular, elements (53-)73-134(-156) × 8-11.5(-12) $\mu \mathrm{m}$, in average $94.7 \times 10.1 \mu \mathrm{m}$. Pigment intracellular, some hyphae with thick wall pigment or encrusting. Clamp connections present in all tissues.

Habitat: Alpine meadow at $2102 \mathrm{~m}$ asl. and close to Alnus viridis (Candusso 1997).

Specimens examined: Italy, Val d'Olen, Alagna Valsesia, P. Jamoni \& M.Candusso 95090601 (MC).

Kühner's material including the holotype

For a description of the macroscopic characters see Kühner 1977, cf. Tab. 1. Our study of the holotype gave following results:

Spores (16/1): (7.2-)7.4-10.1(-10.3) × (3.9-)4.4-5.9 $\mu \mathrm{m}$, in average $8.5 \times 5.1 \mu \mathrm{m}, \mathrm{Q}=1.3-2.2$, Qav = 1.7, inamyloid, predominantly uninucleate (Kühner 1977), ellipsoid, ovoid, oblong to subamygdaloid, occasionally with suprahilar depression, rarely slightly constricted, without globule. Basidia (12/1): (39-)42-54 × 6-7.8 $\mu \mathrm{m}, \mathrm{Q}$ $=6.7-8.1(-8.3), 4,3$, rarely 2 -spored, predominantly cylindric, rarely clavate. Gill edge fertile, cystidia not seen, basidioles scattered. Hymenophoral trama interwoven, elements (10/1): (49-)60-80(-122) × (3.5-)5-12.5 $\mu \mathrm{m}$, cylindric to inflated, in places flexuose; subhymenium interwoven. Pileipellis a cutis $30-40 \mu \mathrm{m}$ thick, more or less differentiated into an upper thin (at most $15 \mu \mathrm{m}$ thick) ixocutis of subradial, \pm repent, partly gelatinised hyphae with terminal elements (8/2): $(34-) 35-68(-86) \times 1.5-2.5(-3.5) \mu \mathrm{m}$, in average $50.8 \times 2.1 \mu \mathrm{m}$, cylindrical, ends obtuse; and a subpellis of interwoven, hyphae with \pm ascending, terminal elements (17/1): (18-)19-48(-69) $\times$ (3-)3.5-4.5(-5) $\mu \mathrm{m}$, in average $41.9 \times 3.7 \mu \mathrm{m}$, subcylindric to tortuous, frequently undulate. Pileitrama subregular to interwoven, elements (19/2): $(26-) 45-70(-96) \times(4.5-) 5-10.5(-13) \mu \mathrm{m}$, subcylindric to irregular, occasionally subinflated. Stipitipellis a thin cutis, $\pm 10-20 \mu \mathrm{m}$ broad of regular, predominantly repent, in places ascending hyphae, terminal elements (10/1): (39-)57-192(-215) × 1.5-2(-3) $\mu \mathrm{m}$, in average $119.8 \times 1.9 \mu \mathrm{m}$, cylindrical, ends obtuse. Stipititrama regular, elements (10/1): (16-)60-100 $\times(1.5-) 6-9(-11) \mu \mathrm{m}$, in average $75.0 \times 7.5 \mu \mathrm{m}$, cylindrical. Pigment intracellular, hyphae occasionally thick walled, rarely encrusting; oleiferous hyphae present. Clamp connections in all tissues, medallion clamps present.

The two otherKühner-collections are similar to the holotype in microscopical features. The spore measurements were: 71-129 (10/1): 8-9.1 × 4.7-5.9 $\mu \mathrm{m}$, in average $8.4 \times 5.2 \mu \mathrm{m}, \mathrm{Q}=1.4-1.9$, Qav $=1.6$; and 73-250 $(16 / 1): 7.6-8.8(-9.6) \times 4.2-5.6(-6.6) \mu \mathrm{m}$, in average $8.5 \times 5.0 \mu \mathrm{m}, \mathrm{Q}=1.3-2.0$, Qav $=1.7$.

Habitat: Only information given by Kühner (1977) is altitude, which for all collections is 2400 $\mathrm{m}$ asl. and that all were found at Salix herbacea and S. reticulata. 


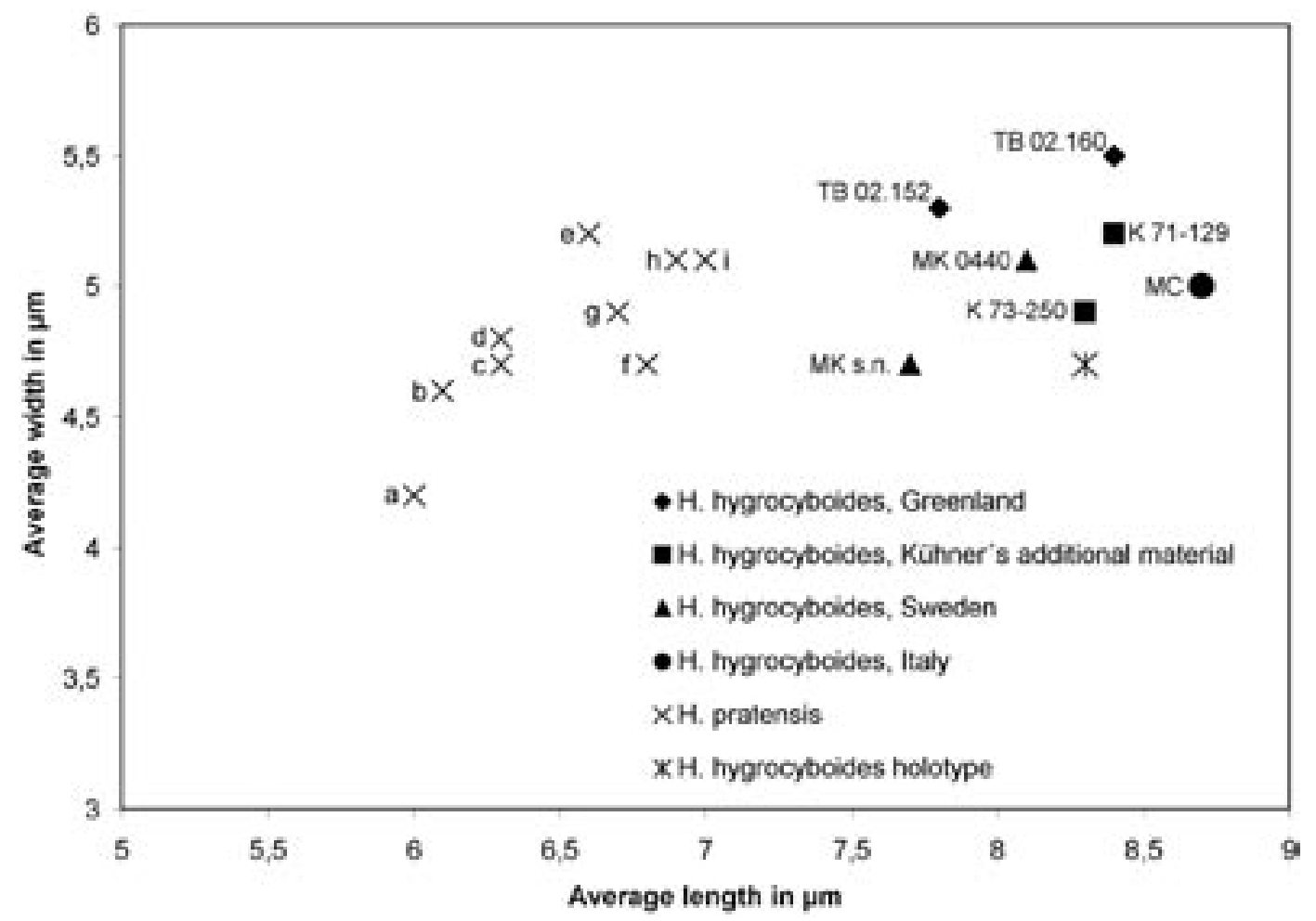

Fig. 4. Scatter diagram showing average spore measurements of the different collections of $H$. hygrocyboides compared with $H$. pratensis. Collections are indicated for $H$. hygrocyboides, cf. material studied sections. H. pratensis: a = TL 2045 (Denmark), b = TB 04.042 (Denmark), c = TB 02.156 (Greenland), d = DB 90044 (Sweden), e = TB 86.339 (Greenland), f= TB 97.206 (Greenland), $\mathrm{g}=$ HK, TB \& JHP 602 (Greenland), h (2 collections) = TB $97.141 \& 95.154$ (both Greenland), I = DB s.n. (Denmark).

Specimens examined: France: Vanoise, Pralognan, Kühner 69-319 (holotype, G, three, somewhat fragmented specimens in fairly good condition) and Kühner 71-129, from the same locality as the holotype (G). Switzerland: Grisons, Val Muraunza, Kühner 73-250 (G).

\section{Hygrocybe pratensis}

For comparison a brief description of $H$. pratensis is provided based on ten collections from Greenland, Denmark and Sweden.

Pileus 23-40(-120) mm, convex, often broadly umbonate, becoming applanate, occasionally infundibuliform, dry and not hygrophaneous. Pale dull orange, orange-brown to buff, Mu. 2.5YR4/6, 5YR5/6 to 10YR7/6. Gills decurrent, pale ochraceous to buff, Mu. 7.7YR6/6-7. Stipe 35-150 × 4-20 $\mathrm{mm}$, cylindrical to somewhat tapering downwards, dry, finely fibrillose, whitish, cream to pale buff, Mu. 10YR8/3. 


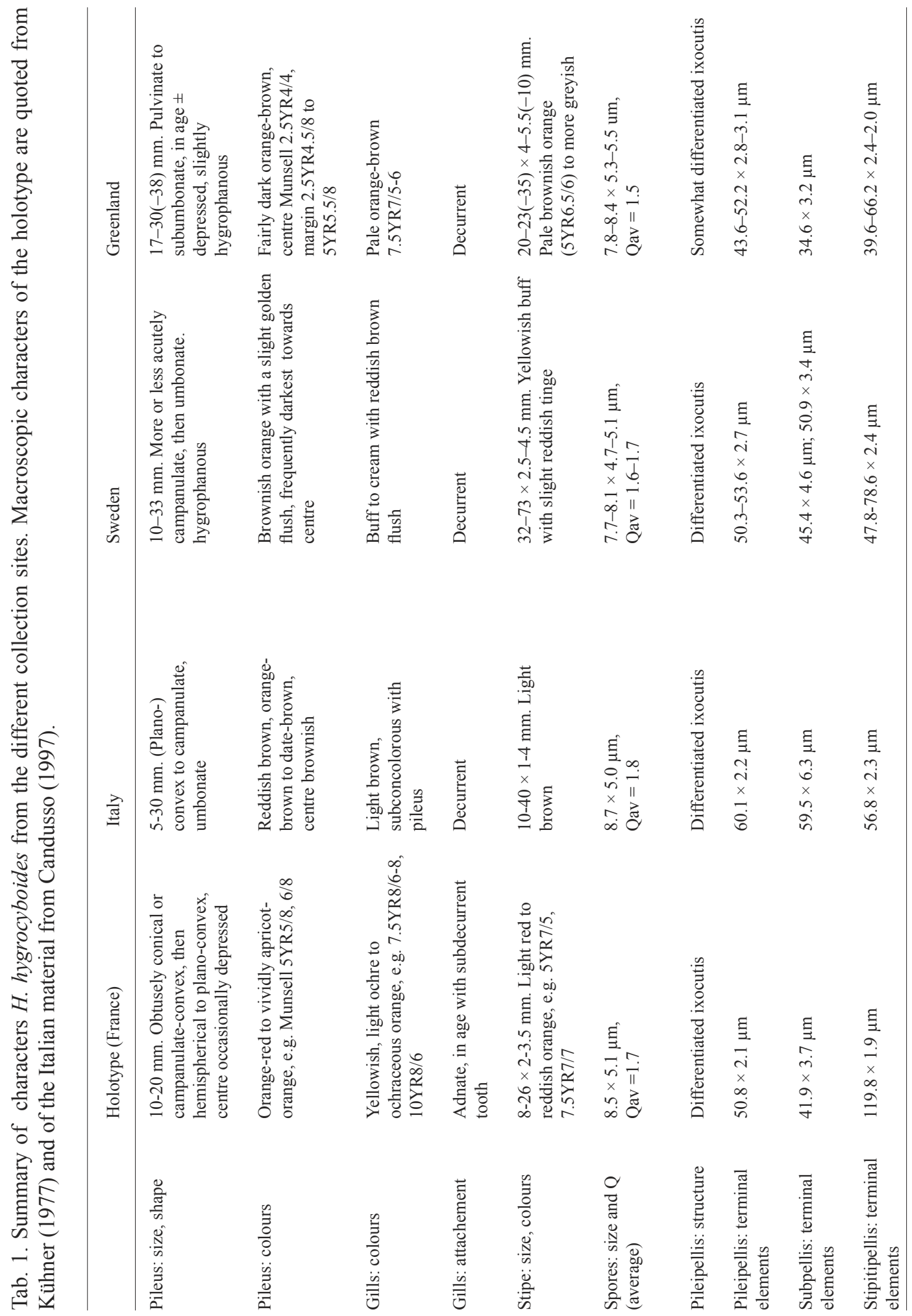


Tab. 2 Spore measurements of the 10 collections of Hygrocybe pratensis compared to the material of $H$. hygrocyboides. $\mathrm{Q}=$ length/breadth quotient.

\begin{tabular}{lccccc}
\hline Collection & $\begin{array}{c}\text { No. of } \\
\text { spores }\end{array}$ & length $\times$ width & $\begin{array}{c}\text { Average } \\
\text { length } \times \text { width }\end{array}$ & $\begin{array}{c}\text { Q } \\
\text { range }\end{array}$ & $\begin{array}{c}\text { Q } \\
\text { average }\end{array}$ \\
\hline TB 86.339 & 16 & $(5.6-) 5.9-7.4(-7.6) \times(4.4-) 4.9-5.6$ & $6.6 \times 5.2$ & $1.2-1.5$ & 1.3 \\
TB 97.141 & 16 & $(6.4-) 6.6-7.4 \times(4.4-) 4.7-5.6(-5.9)$ & $6.9 \times 5.1$ & $(1.2-) 1.3-1.5$ & 1.4 \\
TB 97.206 & 12 & $6.1-7.4 \times 4.2-5.1(-5.4)$ & $6.8 \times 4.7$ & $1.3-1.7(-1.8)$ & 1.4 \\
TB 02.156 & 16 & $(5.9-) 6.6(-7.1) \times 4.2-5.1(-5.4)$ & $6.3 \times 4.7$ & $(1.2-) 1.3-1.5$ & 1.3 \\
TB 95.154 & 16 & $5.9-7.1(-8.3) \times(4.4-) 4.7-5.6(-5.9)$ & $6.9 \times 5.1$ & $1.2-1.5$ & 1.3 \\
HK et al. 602 & 16 & $(5.9-) 6.1-7.4 \times 4.4-5.1(-5.4)$ & $6.7 \times 4.9$ & $(1.2-) 1.3-1.5(-1.6)$ & 1.4 \\
TB 04.042 & 20 & $5.5-6.5(-7) \times 3.9-4.9(-5.1)$ & $6.1 \times 4.6$ & $1.2-1.5(-1.7)$ & 1.3 \\
DB sine no. & 16 & $(6.4-) 6.6-7.4 \times(4.4-) 4.6-5.6(-6.1)$ & $7.0 \times 5.1$ & $(1.2-) 1.3-1.5(-1.6)$ & 1.4 \\
DB 90044 & 16 & $(5.6-) 5.9-6.6(-6.9) \times(4.2-) 4.4-4.9(-5.1)$ & $6.3 \times 4.8$ & $1.2-1.4(-1.6)$ & 1.3 \\
TL 2045 & 10 & $5.6-6.6 \times 3,9-4,7$ & $6.0 \times 4.2$ & $(1.2-) 1.4(-1.6)$ & 1.4 \\
& & & & & \\
\hline
\end{tabular}

Spores 6.1-7.0 × 4.2-5.2 $\mu \mathrm{m}$, Qav = 1.3-1.4 (see details in Tab. 2), ellipsoid, broadly ellipsoid, occasionally subglobose. Pileipellis a non-gelatinised cutis not very well differentiated from trama and with terminal elements measuring 43.4-84.5 × 3.7-5.1 $\mu \mathrm{m}$. Subpellis not observed. Stipetipellis a non-gelatinised cutis with terminal elements measuring 48.2-89.6 $\times 2.8-4.6 \mu \mathrm{m}$.

Specimens examined: Greenland: Paamiut municipality, Eqaluit, TB 86.339 (C); TB 95.154 (C); TB 97.206 (C); Paamiut, near the sea, TB 97.141 (C); Narsaq municipality, Narsarsuaq, at the head of Tunulliarfik, Qanassiassat, HK, TB \& JHP 602 (C); Narsarsuaq, Kiattuut Qaqqaat, TB 02.156 (C). Denmark: Sjælland, Rådmandshave, TL 2045 (C), N Jylland, Vandplasken, DB sine no. (C); E Jylland, Høgdal, TB 04.042 (C). Sweden: Dalsland, Ransliden, DB 90044 (DB).

\section{DISCUSSION}

The material from Greenland and Sweden is referred to H. hygrocyboides, although deviating somewhat in both macroscopical and microscopical characters from the holotype. The Italian collection also deviates from the holotype. However, all are clearly separated from H. pratensis, and no other descriptions in European and North American literature seem to fit (cf. Hesler \& Smith 1963, Bird \& Grund 1979, Kovalenko 1989, Boertmann 1995, Candusso 1997). So, until further material, especially from the Alps, has been studied and described, we prefer to accept the differences as intraspecific variation. A similar intraspecific variation is not unusual among other species within the genus (Boertmann 1995, Borgen \& Arnolds 2004).

The differences can be summarised as: (1) The Greenlandic collections (all rather mature) deviate from the holotype of $H$. hygrocyboides by having darker, brownish colours, a more robust stature, distinctly decurrent gills and slightly broader spores (Figs 1, 4, Tab. 1). (2) The Swedish collections are in accordance with the holotype of $H$. hygrocyboides in stature and spore-size but deviate by having a more pronounced marginal striation on the pileus, distinctly decurrent gills as well as darker stipe (Figs 2, 4, Tab. 1). (3) The Italian collection described by Candusso (1997) deviates from all other collections by having broader elements in subpellis, which are constricted at septa (also constricted in pileitrama), the remaining features are quite similar to the Swedish collections.

The only other taxon, which shows any resemblance to the Greenland and Swedish material, is H. pratensis. However, if we compare H. hygrocyboides and H. pratensis following differences are obvious: (1) The spores of $H$. hygrocyboides are distinctly larger than in H. pratensis (Figs 1-4). (2) In H. hygrocyboides the pileipellis is clearly differentiated from the pileitrama, the elements in the external layer are more or less gelatinised, and the 
hyphae are narrower than in H. pratensis. The pileipellis of the latter is an almost undifferentiated, dry cutis (with some trichodermal elements). (3) H. hygrocyboides differs from $H$. pratensis by having a more bright orange to orange brown pileus (Kühner 1977, Tab. 1) and different, more slender stature (Figs 1,2), although the Greenland material was quite like small basidiocarps of $H$. pratensis. (4) The terminal elements of the stipitipellis are slightly narrower in H. hygrocyboides than in H. pratensis, while the dimensions of the elements in stipititrama are quite similar in both species (Tab. 1).

The Greenland and Swedish records of. H. hygrocyboides are the first from the subarctic and north boreal regions, and are the first outside the Alps.

Kühner (1977) considered H. hygrocyboides to be closely related to H. pratensis within genus Camarophyllus (Fr.) P. Kumm. (= subgenus Cuphophyllus Donk). However, Bon (1984, 1991) and Candusso (1997) treated H. hygrocyboides within Section Oreocybe Boertm. The species of that section, H. citrinopallida (A.H. Smith \& Hesler) Kobayasi, H. lilacina (C. Laest. ex P. Karst.) M.M. Moser and H. xanthochroa (P.D. Orton) M.M. Moser, have omphalioid habit, quite different colours, entirely discolouring basidiocarps, more or less viscid stipe, irregular hymenophoral trama, and \pm differently shaped spores (Boertmann 1990, Borgen \& Arnolds 2004). We are convinced that $H$. hygrocyboides actually belongs to subgenus Cuphophyllus Donk, in accordance with the opinion of Kühner.

\section{ACKNOWLEDGEMENTS}

Thanks to M. Candusso, Alassio and T. Læssøe, Copenhagen and the curators of the herbaria C and G for loan of material. To Mats Karström, Jokkmokk for permission to study and publish his material. Furthermore is T. Borgen indebted to the Flora Agaricina Danica Fund and the J.E. Lange Fund for covering travelling expenses to Greenland in 2002. Two anonymous reviewers gave valuable comments and improved the manuscript.

\section{REFERENCES}

Arnolds, E. 1987. Notes on Hygrophoraceae - X. Three new combinations in Hygrophoraceae. - Persoonia 13: 386.

Athi, T., Hamat-Athi, L. \& Jalas, H. 1968. Vegetation zones and their sections in northwestern Europe. - Annls bot. fenn. 5: 169-211.

Bird, C.J. \& Grund, D.W. 1979. Nova Scotian Species of Hygrophorus. - Proc. Nova Scotian Inst. Sci. 29: 1-131.

Boertmann, D. 1990. The identity of Hygrocybe vitellina and related species. - Nord. J. Bot. 10: 311-317.

Boertmann, D. 1995. Fungi of Northern Europe - vol. 1: The genus Hygrocybe. - Svampetryk, Greve.

Bon, M. 1984. Le Genre Cuphophyllus (Donk) st. n.. - Docums mycol. 14: 9-12.

Bon, M. 1991. Novitates - 3. - Docums mycol. 21: 55-56.

Borgen, T. \& Arnolds, E. 2004. Taxonomy, Ecology and Distribution of Hygrocybe (Fr.) P. Kumm. and Camarophyllopsis Herink (Fungi, Basidiomycota, Hygrocybeae) in Greenland. - Meddr Grønl. Biosci. 54. 
Candusso, M. 1997. Hygrophorus s. 1. Fungi Europaei vol. 6. - Libreria Basso, Alassio.

Corriol, G. 2008. Check-list of Pyrenean alpine stage macrofungi. - Sommerfeltia 31: 29-99.

Clemençon, H. 1978. Siderophilous granules in the basidia of Hymenomycetes. - Persoonia 10: 83-96.

Feilberg, J. 1984. A phytogeographical study of South Greenland. Vascular plants. - Meddr Grønl. Biosci. 15.

Hesler, L.R. \& Smith, A.H. 1963. North American species of Hygrophorus. - Univ. Tennessee, Knoxville.

Kovalenko, A. E. 1989. Ordo Hygrophorales. - Nauka, Filia Leningradensis, St. Peterburg.

Kühner, R. 1977: Agaricales de la zone alpine. Hygrophoraceae. Generalités. Genre Camarophyllus (Fries) Kummer. - Bull. Soc. mycol. fr. 93: 117-144.

Munsell 1975. Soil Color Charts. - Munsell Color Co., Baltimore. 